\title{
EFFECT OF ANTIHYPERTENSIVE
} AGENTS ON STELLATE CELLS DURING LIVER REGENERATION IN RATS

\author{
Leandra N. Z. RAMALHO ${ }^{1}$, Sérgio ZUCOLOTO' \\ Fernando S. RAMALHO ${ }^{2}$, Orlando de CASTRO-e-SILVA Jr. ${ }^{2}$ e Fernando M. A. CORRÊA ${ }^{3}$
}

\begin{abstract}
Background - Although most studies have focused on the hepatocytes, all the hepatic cells participate in the regenerative process, among them the stellate cells. The stellate cells are mesenchymal cells involved in local neurotransmission and paracrine regulation of several liver functions. Acute hepatic tissue loss promotes the proliferation and activation of stellate cells from a quiescent state to myofibroblast-like cells. Aim - Investigate the effects of antihypertensive agents on the stellate cell population during the liver regenerative phenomenon in rats. Methods - Adult male Wistar rats received lisinopril, losartan, bradykinin, or saline solution in a proportional volume, intraperitoneally, before and after $70 \%$ partial hepatectomy. Animals from the experimental and saline groups were sacrificed at 36 hours after partial hepatectomy. The alpha-smooth muscle actin labelled stellate cells population was counted in the periportal and pericentral zones of the liver specimen. Results - The labelled stellate cells were more numerous in the control group both in the periportal and pericentral zones at 36 hours after partial hepatectomy than at the other times. The population of stellate cells was significantly lower in the losartan group and higher in the bradykinin and lisinopril groups than in the control group. Conclusions - These results suggest that losartan can inhibit and bradykinin and lisinopril can stimulate the stellate cell population during liver regeneration in rats. These cells synthesize several substances to stimulate liver regeneration.
\end{abstract}

HEADINGS - Antihypertensive agents. Liver cytology. Liver regeneration. Rats.

\section{INTRODUCTION}

Despite many years of investigation, the detailed nature of the controlling factors that trigger or modulate the hepatic regenerative phenomenon has only recently begun to be understood $^{(17)}$. The increasing studies of the different liver growth factors have enriched our knowledge of the mechanisms regulating liver regeneration. Several cellular growth factors have been progressively identified. The effects of these agents on DNA synthesis have been usually studied in vitro in hepatocyte cultures and in vivo in normal or partially hepatectomized rats $^{(7)}$.
Although most studies have focused on the hepatocytes, all the hepatic cells participate in the regenerative process, among them the stellate cells, also referred to as Ito cells, fatstoring cells or lipocytes. These cells were first described by von Kupffer in 1876. They were "re"discovered by Wake in 1971 , and $\mathrm{KNOOK}^{(15)}$, in 1982, studied for first time metabolic functions in individually cultured cells. The stellate cells are mesenchymal cells located in the space of Disse. Because of this location and connection with sinusoidal and parenchymal cells, they are probably involved in local neurotransmission and paracrine regulation of several liver functions ${ }^{(13)}$. They are the main site of vitamin A storage in characteristic lipid droplets.

Paper carried out at Departments of ${ }^{1}$ Pathology, ${ }^{2}$ Surgery and Anatomy, and ${ }^{3}$ Pharmacology, Faculty of Medicine of Ribeirão Preto, University of São Paulo, Ribeirão Preto, SP, Brazil.

Address for correspondence: Dr. Sérgio Zucoloto - Department of Pathology - Faculty of Medicine of Ribeirão Preto, University of São Paulo - 14049-900 - Ribeirão Preto, SP, Brazil. e-mail: szucolot@fmrp.usp.br 
These cells undergo a process of activation towards a myofibroblastlike phenotype, which has an increased expression of SM $\alpha$-actin ${ }^{(14)}$, and are characterized by increased proliferation, motility, contractility and synthesis of collagens and extracellular matrix components. As a source of growth factors, cytokines, prostaglandins, and others bioactive substances produced in response to noxious agents, they play a crucial role in the mechanisms of liver injury, regeneration and fibrosis ${ }^{(22)}$. They have contractile cytoplasmic processes encompassing the sinusoids and can affect the sinusoidal blood flow. Angiotensin II, one of the final products of the renin-angiotensin cascade, induces stellate cell contraction by a second messenger system that increases the intracellular calcium concentration and stimulates the inositol phosphate metabolism ${ }^{(20)}$. This effect can be inhibited by using losartan, an angiotensin II receptor antagonist (selective $\mathrm{AT}_{1}$ receptor antagonist), with a consequent reduction in portal hypertension ${ }^{(24)}$.

The kallikrein-kinin system exerts a variety of biological effects, including vasodilatation, increased vascular permeability and smooth muscle relaxation or contraction ${ }^{(6,11,21)}$. Angiotensin-converting enzyme (ACE) is also known as kininase II, a powerful bradykinin degrading enzyme $^{(21)}$. ACE inhibitors have two main mechanisms of action: the simultaneous prevention of angiotensin II production and bradykinin degradation ${ }^{(11)}$

The mechanisms by which stellate cells participate in the liver regeneration process and their response to different antihypertensive agents are still little known. The purpose of the present study was investigate the effects of antihypertensive agents on the stellate cell population during the liver regenerative phenomenon in rats.

\section{METHODS}

\section{Animals}

Male Wistar rats (body weight $200 \pm 15 \mathrm{~g}$ ) were housed in a $12 \mathrm{~h}$ light-dark cycled room and were given standard laboratory chow (Purina) and water ad libitum. All animals were treated according to the International Guiding Principles for Biomedical Research Involving Animals (1985) $)^{(5)}$. The animals were divided randomly into two groups, an experimental hepatectomized group and a control hepatectomized group.

\section{Treatment}

The animals of the experimental group were subdivided into three groups: the lisinopril study group $(\mathrm{n}=4)$ received lisinopril (Merck, Sharp \& Dohme, Rahway, NJ, USA) at a dose of $1 \mathrm{mg} \mathrm{kg}^{-1}$ body weight per day, intraperitoneally (i.p.) from 5 days before hepatectomy until sacrifice; the losartan study group $(n=4)$ received losartan (Merck,
Sharp \& Dohme, Rahway, NJ, USA) at a dose of $5 \mathrm{mg} \mathrm{kg}^{-1}$ body weight per day, i.p., from 24 hours before hepatectomy until sacrifice; and the bradykinin study group $(n=5)$ received bradykinin (Peninsula Laboratories Inc., Belmont, CA, USA) at a dose of $1 \mathrm{mg} \mathrm{kg}^{-1}$ and $3^{-1} \mathrm{mg} \mathrm{kg}^{-1}$ body weight, i.p., just after surgery and then at 8 hour intervals until sacrifice, respectively. The control group received a proportional volume of $0.9 \%$ sodium chloride, i.p., from 5 days before hepatectomy until sacrifice.

\section{Partial hepatectomy}

Surgery was performed under ether anesthesia, as described by HIGGINS and ANDERSON ${ }^{(10)}$. Through a $3 \mathrm{~cm}$ laparotomy incision, eventration of the left lateral and medium lobes was performed; the lobes were ligated and excised, corresponding to a resection of approximately $70 \%$ of the whole $\operatorname{liver}^{(3)}$. The control group was subdivided into six groups, five to seven animals per group, that were sacrificed at $0,12,24,36,48$ and 120 hours after surgery to determine the best time to evaluate the stellate cell population. Four to five animals from the experimental groups were sacrificed under ether anesthesia at 36 hours after partial hepatectomy.

\section{Stellate cell evaluation}

The stellate cell population was evaluated by immunohistochemical staining for $\alpha$-smooth muscle-actin on formalin-fixed and paraffinembedded liver tissues. Four $\mu \mathrm{m}$ thick sections mounted on poly-Llysine-coated slides were deparaffinized, rehydrated in an increasing alcohol series, placed in PBS, and treated with 3\% hydrogen peroxide in methanol for 30 min to block endogenous peroxidase activity. Nonspecific protein binding was blocked by preincubation with 5\% normal horse serum diluted in PBS for $30 \mathrm{~min}$. The slides were then incubated with primary monoclonal mouse anti- $\alpha$-smooth muscle-actin antibody (SM- $\alpha$ actin, DAKO A/S, Denmark), diluted 1:400 in BSA, and kept overnight at $37^{\circ} \mathrm{C}^{(3,23)}$. In the second step, the sections were incubated for 35 min with a biotinylated horse anti-mouse immunoglobulin as the second antibody. The reaction product was detected with an avidinbiotin-peroxidase complex and diaminobenzidine was used as a chromogen substrate. Positive and negative controls were used to assess and control for the staining procedure. The slides were evaluated blindly. $\alpha$-smooth muscle actin-positive stellate cells were counted in serial peroxidase-stained sections. In each animal 10 microscopic fields adjacent to portal spaces (periportal, zone 1 of the Rappaport acinus) and 10 microscopic fields adjacent to central veins (pericentral, zone 3 ) located in randomly chosen lobules were evaluated. A square grid was used ( 200 x $200 \mu \mathrm{m}$ under a 50 x objective and an 8 x eyepiece). At this magnification, periportal and pericentral zones were adjacent and representative of the whole lobule ${ }^{(1)}$ (Figure 1). 

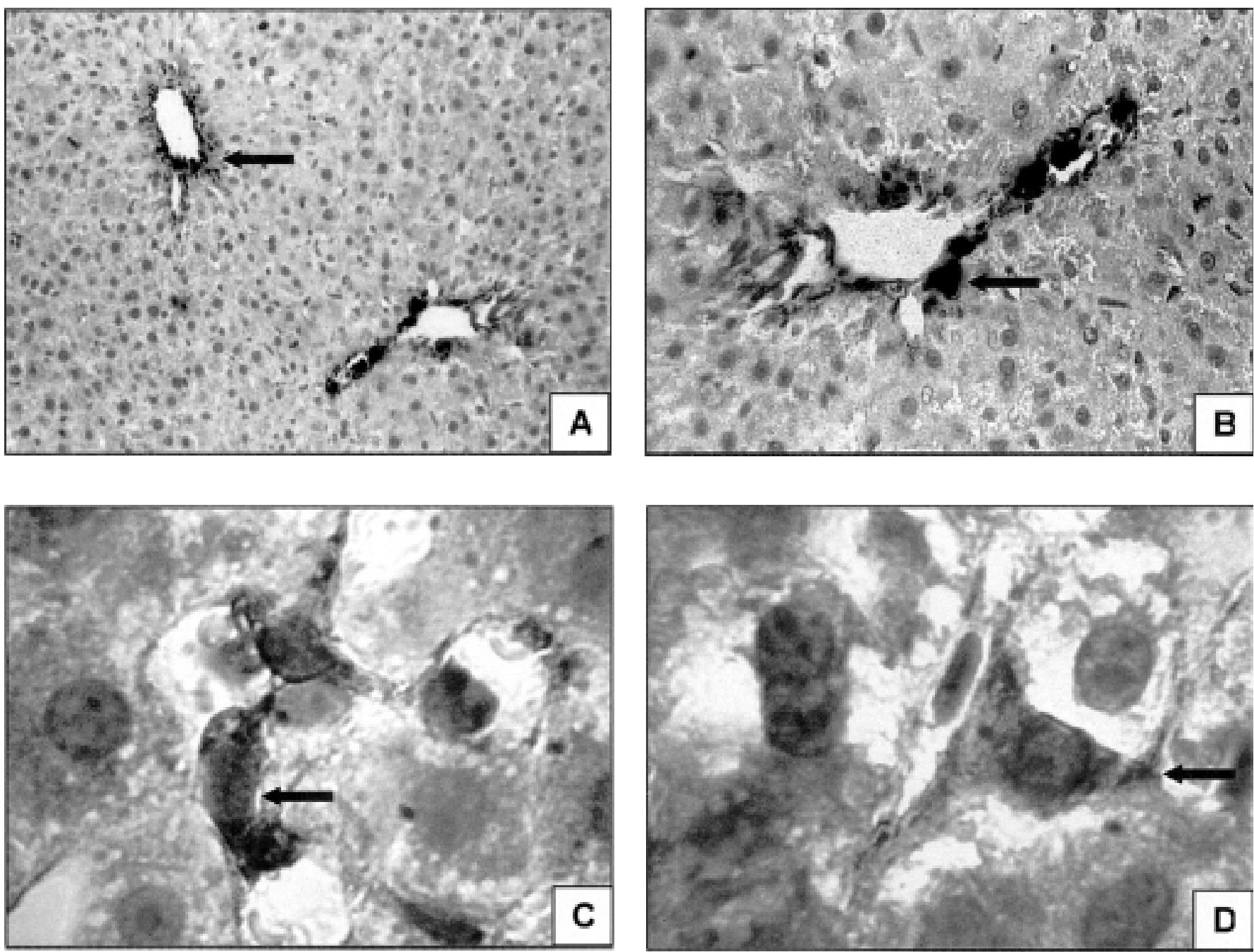

FIGURE 1 - Stellate cells ( $)$ in the pericentral (A) and periportal (B) zones of a hepatic acinus. (Immunohistochemical reaction for $\alpha$-smooth muscle actin - 100x and 200x). Stellate cells ( $)$ in the space of Disse (C and D), with cytoplasmic processes encompassing the sinusoids. (Immunohistochemical reaction for $\alpha$-smooth muscle actin, $400 \mathrm{x}$ )

\section{Statistical analysis}

Data are expressed as mean \pm SEM. Statistical comparisons of groups were performed by analysis of variance for parametric measurements with Bonferroni's or Dunnett's test when appropriate. Probability values $<0.05$ were considered significant.

\section{RESULTS}

The labelled stellate cells were more numerous $(P<0.05)$ in the control group both in the periportal $(18.99 \pm 0.28)$ and pericentral $(9.43 \pm 0.36)$ zones at 36 hours after partial hepatectomy than at the other times (Figure 2). The labelled stellate cells were more numerous $(P<0.01)$ in the periportal and pericentral zones of bradykinin $(30.02$ $\pm 0.40 ; 16.80 \pm 0.27)$ and lisinopril-treated rat livers $(24.60 \pm 0.16$; $13.68 \pm 0.41)$ than in saline-treated rat livers $(18.99 \pm 0.28 ; 9.43 \pm$ $0.36)(P<0.01)$. The labelled stellate cells were less numerous in the periportal zone of losartan-treated rat livers $(15.88 \pm 0.85)$ than in saline-treated rat livers $(18.99 \pm 0.28)(P<0.01)$. No significant difference was observed in the pericentral zones of losartan- $(8.98 \pm$ $0.40)$ and saline-treated rat livers $(9.43 \pm 0.36)$ (Figure 3$)$.

\section{DISCUSSION}

The acute hepatic tissue loss promotes the proliferation and activation of stellate cells from a quiescent state to myofibroblastlike cells ${ }^{(14)}$. In this study, the tissue loss induced by partial hepatectomy determined the highest population of activated stellate 


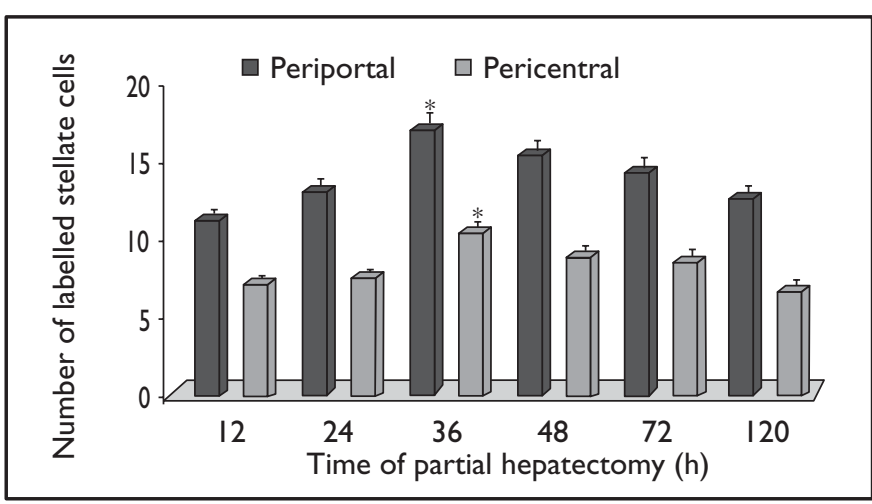

FIGURE 2 - Kinetics of $\alpha$-smooth muscle actin labelled stellate cells in the control groups. Animals were treated with saline solution for 5 days before surgery and on the day of partial hepatectomy. After $0,12,24,36,48,72$ and 120 hours of hepatectomy, the stellate cell population was estimated by counting the $\alpha$-smooth muscle actin labelled cell population in the periportal and pericentral zones of a liver acinus. Data are expressed as mean \pm SEM. The labelled stellate cells were more numerous both in the periportal and pericentral zones at 36 hours $(P<0.05)$ after surgery than at the other times

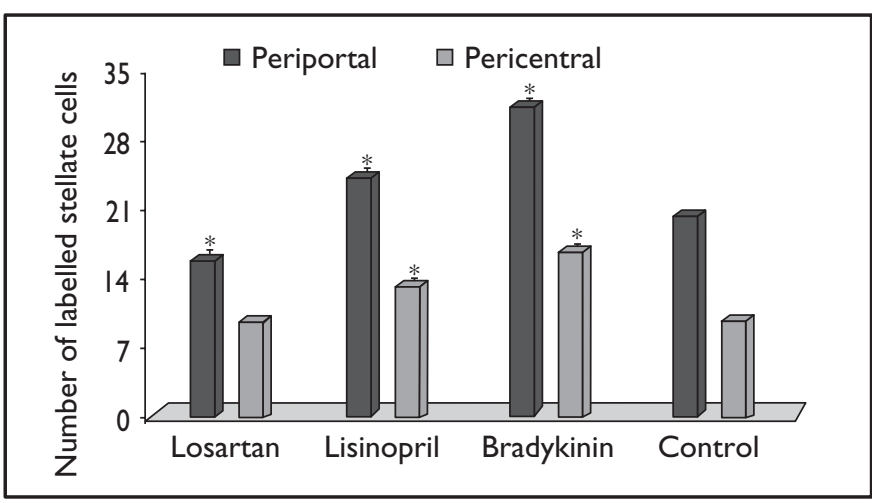

FIGURE 3 - Effect of bradykinin, lisinopril and losartan on stellate cell population. Animals were treated with bradykinin, lisinopril, losartan and saline solution before surgery, and on the day of partial hepatectomy. After 36 hours of hepatectomy, the stellate cell population was estimated by counting $\alpha$-smooth muscle actin labelled cells in the periportal and pericentral zones of a liver acinus. Data are expressed as mean \pm SEM. The stellate cell population was significantly higher in the bradykinin and lisinopril groups and significantly lower in the losartan group compared to the control group $(* P<0.01)$. cells at 36 hours after surgery. The activation of these cells enabled them to produce several growth factors that can promote hepatocellular proliferation, as well as $\mathrm{HGF}^{(2)}$. HGF was initially identified as the most potent growth factor for hepatocytes ${ }^{(18)}$. In addition to being the major suppliers of hepatic HGF, activated stellate cells participate in the hepatic synthesis of extracellular matrix which performs and organizes hepatocellular proliferation ${ }^{(12)}$.

Recent investigations have reported that ACE inhibition increases renal hepatocyte growth factor (HGF) mRNA and cardiac HGF concentration in experimentally hypertensive rats $^{(16,19)}$. The present results showed that the ACE inhibition by lisinopril stimulated the stellate cell population. These data suggest that the improvement of stellate cell population in response to ACE inhibition may also increase hepatocellular HGF production. Nevertheless, the treatment with a specific angiotensin antagonist, losartan, inhibited the stellate cell population. Previous study demonstrated that angiotensin II stimulates activation of stellate cells ${ }^{(20)}$. Because of this inhibitory effect on the activity of stellate cells, losartan can be used in the treatment of portal hypertension ${ }^{(24)}$

Perhaps, the main effect of ACE inhibition on the stellate cell population is not the reduction of angiotensin II synthesis, but the lower hepatic degradation of bradykinin. The mitogenic effect of bradykinin has been reported in many cell types. In mesangial cells, bradykinin and des-Arg'-bradykinin also induced cell proliferation, and this action was potentate by insulin ${ }^{(8)}$. GOLDSTEIN and WALL ${ }^{(9)}$ reported cell division in cultured human lung fibroblasts induced by bradykinin and des-Arg'-bradykinin. PERRIS and WHITFIELD ${ }^{(25)}$ indicated that bradykinin stimulated DNA synthesis in rat thymocite cultures, and bradykinin augments liver regeneration after partial hepatectomy in rats ${ }^{(4)}$.

Very little is known about the importance of the kallikrein-kinin system in the mechanism regulating liver regeneration and its interaction with stellate cells. The present study shows that treatment with bradykinin and ACE inhibitors increases the activated stellate cell population. These cells can synthesize several substances to stimulate liver regeneration. The losartan treatment diminished the activated stellate cell population, which is also known to participate in the liver fibrosis process.

\section{ACKNOWLEDGEMENTS}

The authors thank Ms. Laura M. Kawasse, Ms. Márcia A. O. Destido, and Ms. Ana Maria Abreu for technical assistance. 
Ramalho LNZ, Zucoloto S, Ramalho FS, Castro-e-Silva O, Corrêa FMA. Efeito de agentes anti-hipertensivos sobre as células estreladas durante a regeneração hepática em ratos. Arq Gastroenterol 2003;40(1):40-44.

RESUMO - Racional - Embora a maioria dos estudos focalize os hepatócitos, todas as células hepáticas participam do processo regenerativo, entre elas as células estreladas, que são células mesenquimais envolvidas na regulação de uma série de funções hepáticas. A perda aguda de parênquima hepático induz proliferação e ativação destas células, a partir de estado de quiescência para fenótipo semelhante a miofibroblastos. Objetivo Investigar o efeito de agentes anti-hipertensivos sobre a população de células estreladas durante o fenômeno regenerativo hepático em ratos. Métodos - Ratos machos Wistar receberam lisinopril, losartan, bradicinina ou solução salina, via intraperitonial, antes e após a hepatectomia parcial a 70\%. Animais pertencentes aos grupos experimental e controle foram sacrificados 36 horas após a cirurgia. A população de células estreladas marcadas para a $\alpha$-actina de músculo liso foi estimada nas zonas periportal e pericentral das amostras hepáticas. Resultados - No grupo controle, observou-se maior número de células estreladas ativadas 36 horas após a hepatectomia parcial. A população de células estreladas foi menor no grupo tratado com losartan e maior nos grupos tratados com bradicinina e lisinopril em relação ao grupo-controle. Conclusãa Estes resultados sugerem que o losartan pode inibir e a bradicinina e o lisinopril podem estimular a população de células estreladas durante a regeneração hepática em ratos. As células estreladas sintetizam importantes fatores de crescimento capazes de estimular a regeneração hepática.

DESCRITORES - Anti-hipertensivos. Fígado, citologia. Regeneração hepática. Ratos.

\section{REFERENCES}

1. Ballardini G, Groff P, De Giorgi LB, Schuppan D, Bianchi FB. Ito cell heterogeneity: desmin-negative Ito cells in normal rat liver. Hepatology 1994;19:440-6.

2. Boros P, Miller CM. Hepatocyte growth factor: a multifunctional cytokine. Lancet 1995;345:293-5.

3. Braulio VB, Kouyoumdjian M, Zucoloto S, Figueiredo F, Borges DR. Plasmakallikrein clearance during liver regeneration after partial hepatectomy in the rat. Liver 1998;18:371-7.

4. Castro-e-Silva Jr O, Ramalho FS, Ramalho LNZ, Corrêa FMA, Zucoloto S. Effect of bradykinin on liver regeneration. In: Moreno-Gonzáles E, Hidalgo-Pascual M, editors. Proceedings of the $3^{\text {rd }}$ World Congress of the International HepatoPancreato-Biliary Association. Madrid: Jarpyo; 1999. p.193-5.

5. Council for International Organizations of Medical Sciences (CIOMS), Switzerland. International guiding principles for biomedical research involving animals. 1985. p.1-28.

6. Coutant KD, Ryder NS. Bradykinin upregulates immediate-early gene mRNA in human keratinocytes. Arch Dermatol Res 1996;288:2-6.

7. Fausto N. Hepatic regeneration. In: Zakim D, Boyer TD, editors. Hepatology. A textbook of liver disease. Philadelphia: W.B.Saunders; 1990. p.49-65

8. Girolami JP, Ouardani M, Bascands JL, Pécher C, Bompart G, Leung-Tack J. Comparison of $\mathrm{B} 1$ and $\mathrm{B} 2$ receptor activation on intracellular calcium, cell proliferation, and extracellular collagen secretion in mesangial cells from normal and diabetic rats. Can J Physiol Pharmacol 1995;73:848-53.

9. Goldstein $\mathrm{RH}$, Wall M. Activation of protein formation and cell division by bradykinin and des-Arg'-bradykinin. J Biol Chem 1984;259:9263-8.

10. Higgins GM, Anderson RM. Experimental pathology of the liver: I. Restoration of the liver of the white rat following partial surgical removal. Arch Pathol 1931; 12:186-202.

11. Ito $\mathrm{K}$, Zhu Y, Gohlke P, Unger T. Contribution of bradykinin to the cardioprotective action of angiotensin converting enzyme inhibition in hypertension and after myocardial infarction. Jpn J Pharmacol 1997;75:311-8.

12. Jiang WG, Hallett MB, Puntis MCA. Hepatocyte growth factor/scatter factor, liver regeneration and cancer metastasis. Br J Surg 1993;80:1368-73.

13. Kawada N. The hepatic perisinusoidal stellate cell. Histol Histopathol 1997; $12: 1069-80$
14. Knittel T, Kobold D, Piscaglia F, Saile B, Neubauer K, Mehde M, Timpi R, Ramadori G. Localization of liver myofibroblasts and hepatic stellate cells in normal and diseased rat livers: distinct roles of (myo-) fibroblast subpopulations in hepatic tissue repair. Histochem Cell Biol 1999;112:387-401.

15. Knook DL. Fat-storing cells of the rat's liver. Their isolation and purification. Exp Cell Res 1982;139:468-71.

16. Matsumoto K, Morishita R, Moriguchi A, Tomita N, Yo Y, Nishii T, Nakamura T, Higaki J, Ogihara T. Prevention of renal damage by angiotensin II blockade, accompanied by increased renal hepatocyte growth factor in experimental hypertensive rats. Hypertension 1999;34:279-84.

17. Michalopoulos GK. Liver regeneration: molecular mechanisms of growth control. FASEB J 1990;4:176-87.

18. Nakamura T, Nishizawa T, Hagiya M, Seki T, Shimonishi M, Sugimura A, Tashiro $\mathrm{K}$, Shimizu S. Molecular cloning and expression of human hepatocyte growth factor. Nature 1989;342:440-3.

19. Nakano N, Moriguchi A, Morishita R, Kida I, Tomita N, Matsumoto K, Nakamura T, Higaki J, Ogihara T. Role of angiotensin II in the regulation of a novel vascular modulator, hepatocyte growth factor (HGF), in experimental hypertensive rats. Hypertension 1997;30:1448-54.

20. Pinzani M, Failli P, Ruocco C, Casini A, Milani S, Baldi E, Giotti A, Gentilani P. Fat-storing cells as liver-specific pericytes. Spatial dynamics of agoniststimulated intracellular calcium transients. J Clin Invest 1992;90:642-6.

21. Regoli D, Barabé J. Pharmacology of bradykinin and related kinins. Pharmacol Rev 1980;32:1-46.

22. Rippe RA. Life or death: the fate of the hepatic stellate cell following hepatic injury. Hepatology 1998;27:1447-8.

23. Roskams T, van den Oord JJ, De Vos R, Desmet VJ. Neuroendocrine features of reactive bile ductules in cholestatic liver disease. Am J Pathol 1990;137:1019-25.

24. Schneider AW, Kalk JF, Klein CP. Effect of losartan, an angiotensin II receptor antagonist, on portal pressure cirrhosis. Hepatology 1999;29:334-9.

25. Perris AD, Whitfield JF. The mitogenic action of bradykinin on thymic lymphocytes and its dependence on calcium. Proc Soc Exp Biol Med 1969; $130: 1198-202$

Recebido em 19/7/2002. Aprovado em 16/12/2002. 